\title{
Academics' Perceptions on the Factors Affecting Strategic Changes: The Case of an Australian University
}

\author{
Mamun Billah \\ Western Sydney University, Australia \\ E-mail: m.billah@westernsydney.edu.au \\ Mehadi Mamun (corresponding author) \\ Victorian Institute of Technology, Australia \\ E-mail: mehadi.mamun@vit.edu.au
}

Received: August 24, 2021 Accepted: September 16, $2021 \quad$ Published: October 5, 2021

doi:10.5296/ijld.v11i3.18960ＵRL: https://doi.org/10.5296/ijld.v11i3.18960

\begin{abstract}
Over three decades, a number of external and internal factors that are linked to the political and economic environment have influenced Australian universities to adopt strategies and management styles similar to any other business organisation. The shifts in the strategic focus of the universities have been reflected through their policies and governance at different levels of the organisations. However, there is a need for understanding from different levels' staff perceptions on whether they equally perceive the changes as legitimate. Based on a social constructionist approach, utilising the intellectual merits of Institutional Theory, this paper draws on the in-depth interview of three levels of staff of an Australian university to understand their perceptions on the impact of major influential factor(s) responsible for strategic changes in their operating environment. The study finds that academics at different levels carry a mix of attitudes towards identifying the major influential factors, not by its merit but rather the way the top managements have implemented the changes within the organisation. The study also finds that the strategy implementation that is based on the new business model and adopted by the University has not been positively accepted by the operational level academics as it conflicts with their traditional values. The perception gaps at different levels identified in the study would help management in future strategy development and the implementation process with a stronger focus on the behavioural aspects of change.
\end{abstract}

Keywords: Australian universities, Strategy, Policy, Academics' perceptions 


\section{Introduction}

Over the past three decades, Australian universities have been continuously adopting new strategies and policies to meet demands from its external and internal factors that are linked to Australia's economic and political environment. The most notable of these demands areincreased competition in the global and domestic market; changes to a market-based philosophy; changes in the government perspective on the higher education sector; greater emphasis on strategic alliances; and increased public interest in higher education (Shin \& Jung, 2014; Parker, 2011; Caruana \& Pluner, 2010; Moll \& Hoque, 2004; Scott, 2004). The adoption of new strategies and policies has caused transformative changes in the organisational structures, governance, and management style of Australian universities. The transformative changes in strategies and management style (with operating measures similar to those in any commercial organisation but often unfamiliar to the internal higher education organisation constituents) have placed pressure on academics to alter their attitudes to positively accept and embrace the changes and to alter their operational actions to conform, at all levels, to those of the organisations. Although contemporary evidence available on perceptions study on university staff impacted by the above internal and external factors (see Shaw, 2013; Anderson, 2008; Deem \& Morley, 2006; Taylor \& Bedford, 2004), the analysis of differentiation on perceptions among academics at different levels is not common in those studies. Hence, the purpose of this paper is to analyse staff perception from different levels of a university on the major influential factors responsible for the above changes. In particular, this paper attempts to highlight the differences in perceptions among staff across different levels and disciplines in identifying most internal and external factors responsible for changes in strategies, policies and organisational structure.

\section{Literature Review}

Since 1980s, there has been transformative changes in the Australian higher education sector due to increased competition, internationalisation and globalisation of business, reduction of government funding, greater emphasis on strategic alliances, increased consumer criticism in terms of the quality of the services including the sophistication of delivery, and greater public interest in higher education (Parker, 2013, 2011; Vaira, 2004; Blackmore, 2002; Porter \& Vidovich, 2000). Government as the most significant external stakeholder have adapted new perspective on higher education as the prime source of export earnings that contributes to the engine room of national economics (Parker, 2013). Government demand on the universities to adopt neo-liberal market philosophy reflected through a series of higher education reforms pushed the universities to shift their strategy, policy directions and governance structure quite frequently (Parker, 2011; Jones et al., 2006).

Therefore, over the three decades there has been rapid changes in the governance, core activities, stakeholder relationships and academic work where the internal stakeholders of a university organisation in Australia experienced significant strategic changes related to the core activities of teaching and learning, research, and engagement (Parker, 2012; Bobe \& Taylor, 2010). There were changes in internal resource allocation process focused on revenue generation and cost efficiency, enhanced accountabilities and reporting responsibilities and 
the use of performance measures for staff evaluation. The impact of these changes ultimately influenced individual staff attitudes and operating behaviours (Bexley et al., 2011; Mapsela \& Hay, 2006). Especially, the government demand on the universities has been for more accountable and responsible handling of public money and reduced dependency of the universities on the public purse.

The above-mentioned changes have had a consequential and detrimental impact on staff attitudes (Parker, 2013; Bexley et al., 2011). This requires an examination of staff perceptions at different levels within the institution in how they perceive as the dominant factor for changes. What is specifically unique is viewing the impact of the environmental factors from staff perception, comprehending how individual staff, at different levels of the institution, perceive the environmental/social pressures as being significant enough to warrant changes in the university's strategic direction achievement of the new strategic goals. The following section covers staff perceptions on the above phenomenon and indicates the need for further extended understanding of the same.

\subsection{Staff Perceptions}

A number of studies use staff perceptions on the impact of the above phenomena. Anderson (2006) interviewed 27 academics from eight Australian universities on their experiences of managerialism. Their analysis focuses on academics' experiences of time and space in the managerial university. Academics in this study argued that managerial practices in their universities imposed significant time-burdens in already full workloads. Anderson (2008) interviewed 30 academics in ten Australian universities to explore the phenomenon of academic resistance to managerialism. A survey on 2609 academics in four types of the university by Winter and Sarros (2000), identified that although academics remain very attached to their jobs/work activities, they do not exhibit the same levels of attachment to their institutions. They considered the environment of consumerism in higher education as fluid where leadership is most needed but least valued. The study by Mapsela and Hay (2006) conducted a questionnaire survey on lecturing staff on how the internal and external factors affected the satisfaction of academic staff in the transformation. Their study sought to inform how the new demands for technology, globalisation, internalisation, increased accountability, a new mode of delivery, and dwindling higher education resources placed pressures on staff.

From internal factor perspectives, some studies considered that organisational restructuring was a common response by the HES to meet the demand from the external pressures (Parker, 2013, 2011; Blackmore, 2002; Gumport, 2000). Some studies focus on the consequential changes in organisational structure, for example, the survey conducted by Meek (2002, pp. 266-267) of VCs (Vice-Chancellors) and DVCs (Deputy Vice-Chancellors), Deans of Faculty and Heads of Departments/ Schools across all Australian universities on the appropriateness and effectiveness of management and governance structure and procedures. Santiago et al. (2006) surveyed mid-level managers on their perceptions and attitudes on the impact of managerialism in higher education, Taylor et al. (1998) survey was related to the perceptions of academic staff on the changes in core activities.

The above studies either consider the collective views or a section of stakeholders' 
perspectives impacted by the changes. In this paper, it is argued that not all the factors uniformly impact staff at all levels, and as such their perceptions on the major environmental factors are also different. It is assumed that due to their level of attachment to the organisation, their perception can differ in identifying the most influential factors responsible for strategic changes in their organisation. Therefore, the authors would like to understand the perceptions of three levels of university staff ranging from senior level (i.e., VC, DVC, Executive), mid-level (i.e., PVC, Dean, associate dean), and academic level. It is argued that identifying the difference would add value to management in the future design and implementation of the strategy. Based on the above contention, the following research question has been developed-

How university staff at different levels perceive the impact of the external and internal factors responsible for strategic changes?

It is envisaged in this research that understanding the perceptual gaps among staff at different levels in the staff structure would facilitate better strategic planning and implementation in the future and would lead to higher levels of goal alignment between the university and individual staff.

\section{Methodology}

\subsection{Theoretical Framework}

This paper used Institutional theory to expose the staff perceptions on the environmental factors (external and internal) affecting the changes in strategy, policy, and organisational structure. The theory defines organisational environment (Gates, 1997) and shows how organisations behave in response to market and institutional pressures (Greenwood \& Hinings, 1996). Many aspects of an organisation's formal structure, policies and procedures serve to demonstrate conformity with the institutionalised rules and expectations expressed by external constituents (DiMaggio \& Powell, 1983). The theory assumes that a primary determinant of organisational structure is the pressure exerted by external and internal constituencies on the organisation (Brignall \& Modell, 2000). The theory argues that organisations are more complex settings with environmental pressures, and not merely internal technical requirements, shaping organisational structures and accounting for the diversity of organisations (Scott, 2008). The environmental pressures by which they are shaped include the beliefs, fashions, regulatory requirements, and desires of important external institutions (Major \& Hopper, 2003).

There has been a widespread application of the institutional perspective in higher education sector research (i.e., Morphew \& Huisman, 2002; Bealing et al., 1996), and it is expected, in the current research context, that the theory can be helpful to understand how the organisational participants perceive the major influential responsible for changes in strategy, policy, and organisational structure. The theory provides a much-needed theoretical toll, which can be used to better understand the factors that precipitate academic drift.

\subsection{Case Selection and Data Collection}

For understanding the research phenomenon, a single large university in the Greater Western Sydney area has been selected. On the matter of global and domestic environmental 
influences, there are many similarities in the impact on universities (globally and locally). To minimise the lack of external validity, the following characteristics of the case study organisation were considered in assessing that it was a suitable subject for investigation. The case university selected for this research was formed as a direct impact of government higher education policy reform that combined former educational institutions in which the staff had their own unique organisational cultures and control systems. Considerable effort had been previously spent on integrating these prior institutions into consolidated organisations. Given the limited resources for the research, it was necessary to focus on one case study and this university was particularly interesting due to the major restructuring during the higher education reform period. It allowed consideration of whether that traumatic experience influenced the responses to the strategy, policy and governance being studied. Most of the impact of the government policy reforms on the higher education sector started to become visible through the adoption of different strategic goals by the universities at large for which many of the measures, previously seen as inappropriate by the higher education sector, were copied from other sectors (Hammer \& Star, 2004; Coaldrake \& Stedman, 1999).

Staff perceptions are evaluated through face-to-face interviews between the researchers and the interviewees with this considered the prime source of information for this research. Interview invitations were sent to 33 academics across a number of disciplines and 19 agreed to participate. The interviewees have been classified into three broad levels to understand the perception gaps between these levels. The selection criteria of the interviewees were the interviewees must have been a staff member of the case study organisation, continuing staff, and had experienced the changes during the strategy implementation process. Throughout the different levels of the organisation, some had been initiators of the strategic changes (a majority of these were top-level staff), some had been used as the levers of control for the implementation of the intended strategic changes (mainly the middle-level management), while a significant number had carried out core activities (teaching and learning, research, and engagement) as per the strategic plans pushed down from the upper levels. Furthermore, the selection criteria of academic-level interviewees (Group Three), has been further classified as the changes in strategies and operative measures are related to the three core activities: teaching and learning (T\&L), research, and community engagement (engagement).

\section{Group One: Top management}

Participants in this category were engaged in negotiating with the external environment and assessed the consequences of any pressure/demand on the organisation and contemplated the proposed changes to be implemented organisation-wide. The majority of them had been initiators of the strategic changes. Therefore, it was important to know the views of these senior executives in understanding the impact of the external pressures that they faced and how they adopted the changes to operationalise the strategies within the organisation. All the participants were the staff members of the university who had experienced the strategic changes due to the pressures from internal and external factors.

\section{Group Two: Middle management}

Staff at this level was used as levers of control for the implementation of the intended 
strategic changes who played a vital role in the implementation of plans passed on to them from the top. One of the major responsibilities of this group was to negotiate the implementation of the changes with the academic-level staff and to provide feedback to the top on the negotiation processes. In addition, they needed to gather knowledge on the perception of top management and the academic level about the change process combined with their own perceptions of reality.

\section{Group Three: Academics at the operational level}

Interviewees at this level were engaged with three core activities of the university (i.e., teaching and learning, research, and engagement), and had a more direct impact on their day-to-day operational activities than on those of the general staff.

Table 1. Category of the interviewees and their numbers

\begin{tabular}{llll}
\hline Job Title & Responsibilities & $\begin{array}{c}\text { Number of } \\
\text { Interviewees }\end{array}$ & Basic Role in the Change Process \\
\hline Group one: Top Management & & \\
\hline $\begin{array}{l}\text { DVCs, } \\
\text { PVCs, CFO }\end{array}$ & $\begin{array}{l}\text { Change leaders and } \\
\text { planners }\end{array}$ & 3 & $\begin{array}{l}\text { Engaged in the design and overall } \\
\text { implementation of the strategic plan } \\
\text { throughout the organisation }\end{array}$ \\
\hline Group two: Middle Management & & $\begin{array}{l}\text { Engaged in the implementation of } \\
\text { the strategic plans passed on from } \\
\text { top and and } \\
\text { communicating with Groups 2 and } 3\end{array}$ \\
$\begin{array}{l}\text { Assoc. Deans } \\
\text { and Heads of } \\
\text { Schools }\end{array}$ & 6 &
\end{tabular}

\section{Group three: Academics}

Professors,

Assoc. $\quad \underline{\text { Operations }}$

Professors, T\&L-focused

Senior

Lecturers

T\&L and Research-

and focused

Adapting to the changed policies

Lecturers

Associate

$\mathrm{T} \& \mathrm{~L}+$ Research +

Lecturers

Engagement focused 
Hence, the Group Three (ten academics) interviewees were chosen on the basis of their involvement in the core operational activities. The major purpose of using the core activity-related questions was to ensure that the staff perceptions collected covered the three core activities and were properly reflected in the interview questionnaires. It was also perceived that the selection of academic staff solely on the basis of engagement activity would be a difficult choice because T\&L and research are the major activities in order of priority for any academic staff member for any university and engagement activities are usually ancillary to these two. Therefore, it is presumed that, in terms of engagement, an academic's roles can be linked with engaged teaching or engaged research, or both, whereas an academic's job based only on engagement is exceptionally rare.

A semi-structured interview was developed where the interviewees were asked some general questions to initiate conversation and a number of questions were specifically targeted to the participants depending on their position in the organisational hierarchy. Broad information related to globalisation, internationalisation, government higher educational reform, governance, policy, resource allocation process were classified into (1) broad general questions on what is the most significant factor responsible for changes; and (2) questions related to their operational environment -why and how the significant factor affect their day to day operational tasks. The recorded versions of interviews were used in parallel to the transcriptions for coding and analysis particularly in relation to tone and context. The transcribed data were simultaneously coded using the QSR NVivo ${ }^{\text {TM }}$ Version 10 software: the coded responses were provided as input to the main analysis table developed for in-depth scrutiny of the responses and to interpret the findings. The data analysis process started with the reading of a single interview transcript from each interview group without any preconceived coding scheme in mind. Initially the purpose of selecting a single transcript from each group was to conduct a comprehensive analysis of a single interview to identify pattern(s) of the responses and to search for similar patterns or to find something unique compared to what had been identified in the literature.

\section{Findings}

The following interview analyses presented staff perceptions on the major external and internal factors responsible for the strategic changes of the University.

\subsection{External Factors}

It was found that every participant among the three groups identified the role of government as the major influential external factor responsible for the strategic changes with somewhat different interpretations of the same factor due to perceptual variation shaped by their operational environment. The Group One (top management) participants, for example, displayed a more holistic and outward-looking perspective who showed a better understanding of the link between globalisation and consequent changes in government policy reforms, increased competition both at the domestic and international market, the internal fund allocation process, students and staff relationships. They believed that these factors were interrelated. It was clear from their views that ranking of the pressure was an important part to their strategy development tasks. Top management interviewees' first 
priority was to adapt the government's reforms for securing funding and was equally necessary for gaining legitimacy.

However, participants in Group Two believed that it was the Government Immigration Policy that had significantly increased student numbers and considered it as the biggest external influential factor but contended that they did not receive any extra funding as a result. For the Group Two participants, the funding per student posed a challenge for the mid-level managers because they had to convince the operational level to do more with fewer resources. Interviewees of the Group Three mainly focused on the consequential changes in their operating environment related to the core activities of teaching and learning, research, and engagement. One Group Three interviewee said that instead of distinguishing between internal and external factors when prioritising changes, it was the top management and the decision of the governing body that matters and as such was the most influential factor for change. Additionally, staff at the Group Three believed that government reforms actually resulted in the concentration of power at the top and thus damaged the traditional collegial atmosphere of their university.

Due to the substantial inflow of international students, some Group Two participants considered that as one of the major influencing factors for the Universities to change their strategies to attract overseas students. A similar experience was also shared by a Group Three participant: 'that [student numbers] was an external factor that clearly impacted upon the university' (Group Three Interviewee). Due to the increase in the number of full fee-paying students, the University had also to adapt new strategies that impacted on the traditional staff-student relationships, that was, considering students as 'clients', education as a product, pressure for documented quality as evidenced by student feedback, and increase accountability that impacted on staff attitudes towards the strategic changes, especially how the University shifted the extra load of pressures onto the academics. It was revealed that in spite of increasing student numbers, the university was affected because of the reduction of funding by the government, and the way the fund was allocated to the mid-level. The pressure created negative attitudes towards the increasing student numbers. Some Group Two interviewees also believed that funding was related to the unemployment condition in the economy, during unemployment more students came to the university and the opposite happened when the unemployment rate decreased. 
Table 2. Interviewee responses on major external factors

Group $\begin{aligned} & \text { Responses } \\ & \text { identified) }\end{aligned}$ (Pressures for change Impact

- Government funding policy

One

- International competition

The old funding model was replaced with a new one, which would mean a

- Pressure for internal restructuring reduction of tens of million dollars. to become more efficient.

- Government Policy

- Changes in permanent residency rules by the government

- Competition for full fee-paying students

Reduction of funding, cost, increased

Two

- Increase in accounting and accountability on the university that reporting responsibilities spread to the departmental level.

- Community expectations

- National economic condition unemployment problems

- Government funding

- Pressure on the university to rationalise and improve efficiency

- Changes in permanent residency rules

Three

- Community expectations

The community was upset as a consequence of course cuts.

- Political Environment

- The governing body's decisions, in response to recommendations of the executive.

\subsection{Internal Factors}

It was found that the changes of strategic directions due to the above external pressures brought about significant changes in the internal organisational environment. Interviewees' 
responses on the internal factors for changes in strategic directions identified a small number of factors responsible for the strategic changes and the majority of them appeared as a consequential impact of the external factors. For example, the restructuring of organisation structure was a direct impact of the government policy directives.

There were clear differences in views between the top management and the operational level academics. Group One participants had quite different perceptions in regard to the impact of the internal factors and their views were shaped by the role they played in the strategy development process. A Group One interviewee did not consider that there was any internal pressure for changes other than the development imperative, that was, the need to have a unified vision was the internal pressure for change. As achieving legitimacy was the main challenge, they believed that it was the vision that was important to share among the organisational participants. It was mentioned previously that gaining legitimacy was important for top management to ensure funding.

Responses of Groups Two and Three revealed that their perceptions of changes were related to internal resource allocation processes, restructuring of organisational units, changes in leadership and managerial styles. Several restructuring processes undertaken by the University were considered as significant internal factors by the participants. Most of the Group Three interviewees, for example, considered that the merger of accounting and administrative activities was the most important one. It was also identified that the resource allocation process was one of the most influential internal factors that had affected all groups. With the changes in the government funding policy, the University had to change its Resource Allocation Model several times and that had affected staff perceptions at all levels. The demand for a transparent funding model was the consequence of the restructuring process when there was a significant turnover of staff at senior positions. At the Deans and Head of School levels, many of such positions were replaced by individuals employed with designation as professional managers on a contract basis rather than academics who were given specific targets to achieve. One interviewee from the Group Two considered that the demand for more allocation of resources was one internal factor that created pressure to change the funding policy of the University. It had a major impact on the mid-level and operational level, a majority of the Groups Two and Three interviewees acknowledged the event as significant changes in leadership positions and management styles that impacted on their operational environment. Moreover, the departure of senior staff that were replaced by professional managers and new management styles had behavioural impacts on different levels, which created tension among staff as it resulted in a reduction of academic freedoms and a loss of power at different levels. Their leadership styles were different from the traditional collegial styles and had impacted on those subordinates to them. 
Table 3. Interviewee responses on major internal factors

- Restructure of academic programs and organisational units

Group One (Top management)
- Demand from internal stakeholders for more transparent resource allocations

- The single other biggest thing was the university understanding what kind of university it wanted to be

- University restructuring (i.e., four colleges were reduced to three

Group Two

(Mid-level management) colleges.)

- Movement of senior staff, underinvestment of resources for a blended learning environment

- The internal resource allocation process

- Restructuring, increased workload

Group Three

- Changes in leadership

(Academic staff)

- New organisational culture, and reduction of academic freedoms

- Internal resource allocation processes

\section{Conclusions}

The main purpose of this study has been to analyse academic staff perceptions to understand how the academics at different levels view the external and internal factors that are significant for strategic changes. The research finds that staff at different levels hold different attitudes in identifying the most influential factors which are shaped by their roles and responsibilities and level of exposure to the external environment. The government funding has been correctly identified by the three groups of interviewees as the most influential for strategic changes, but each has different perceptions in considering it as a dominant factor. It is found that the University has to prioritise the demand from the external environment in line with the government policy directions. For example, the University undertakes a massive cost-cutting strategy and discontinues many traditional courses or units to manage the reduction of funding from the government. For the top management, the strategic changes are approached from the resource dependence perspective. Middle-management's view is shaped by both the top and the bottom level staff, and the analysis of staff interviews of those at the operating level view the significance of any factor not on its own merit but rather based on the way that the University adopts changes within the organisation.

There are also differences in perceptions among the different levels of interviewees on whether there are internal pressures for changes. The differences in attitudes towards the 
internal pressures for changes due to their roles and responsibilities in the change process, and communication gaps among the different levels. One of the significant reasons for perception gaps between the top management and the operating level staff is the replacement of senior staff with new ones as professional managers that introduce new managerial styles. It creates negative attitudes among operating level staff and creates communication gaps between the top and operating levels due to decoupling behaviour by the new managers. Interviewees' responses show that the top management perceptions on the internal factors are to some extent influenced by the reports and information from the mid-level that are filtered (in some cases) in terms of what it conveys about the reality as perceived by the operating level staff. The mid-level group views the internal pressure for changes in the opposite way, they see the top management's action impact on their implementation of core activities, and in some instances, they work as a neutralising force against the pressures from the top and operating levels. It is also found that the internal factors are the consequences of the impact of the pressures from the external environmental pressures. For example, the restructuring of organisation structure is a direct impact of the government policy directives. The effect of the organisational restructuring is so strong that some interviewees consider it as an external pressure, which has affected the traditional organisational values and belief systems. Hence, the staff at different levels identify factors, which are linked to one another and can be ranked in order of importance. Except for the funding and restructuring issues, the sequence can be different depending on how their attitudes are shaped by their operating environment.

In sum, it can be said that this study categorically presents the decoupling behaviours displayed by the different staff at different levels of a university organisation that can be an important understanding for future strategy implementation. However, in this study staff were categorised into three levels based on the roles and responsibilities in the organisational hierarchy. A total of 19 individuals agreed to participate in the interview session. The major findings and contributions are based on their views and opinions; it is not known whether further participation would provide more insights into the phenomenon investigated. It is also necessary to know intra-group/intra-discipline perception gaps in detail, which inform the scope for further research.

\section{References}

Anderson, G. (2008). Mapping academic resistance in the managerial university. Organization, 15, 251-270. https://doi.org/10.1177/1350508407086583

Bexley, E., James, R., \& Arkoudis, S. (2011). The Australian academic profession in transition. Centre for the Study of Higher Education, The University of Melbourne.

Bealing, W. E., Dirsmith, M. W., \& Fogarty, T. (1996). Early regulatory actions by the SEC: An institutional theory perspective on the dramaturgy of political exchanges. Accounting, Organizations and Society, 21(4), 317-338. https://doi.org/10.1016/0361-3682(95)00024-0

Blackmore, J. (2002). Globalisation and the restructuring of higher education for new knowledge economies: New dangers or old habits troubling gender equity work in universities? Higher Education Quarterly, 56(4), 419-441. 
https://doi.org/10.1111/1468-2273.00228

Bobe, B. J., \& Taylor, D. W. (2010). Use of management control systems in university faculties: Evidence of diagnostic versus interactive approaches by upper echelons. Paper at Asia Pacific Interdisciplinary Research in Accounting (APIRA) Conference, May.

Brignall, S., \& Modell, S. (2000). An institutional perspective on performance measurement and management in the 'new public sector'. Management Accounting Research, 11, 281-306. https://doi.org/10.1006/mare.2000.0136

Caruana, V., \& Ploner, J. (2010). Internationalisation and Equality and Diversity in Higher Education: Merging Identities. Project Report: Equality Challenge Unit (ECU).

Coaldrake, P., \& Stedman, L. (1999). The changing higher education landscape: Pressures on university work. Department of Education, Training and Youth Affairs, September.

Deem, R., \& Morley, L. (2006). Diversity in the Academy? Staff Perceptions of Equality Policies in Six Contemporary Higher Education Institutions. Policy Futures in Education, 4(2), 185-202. https://doi.org/10.2304/pfie.2006.4.2.185

DiMaggio, P. J., \& Powell, W. (1983). The iron cage revisited: Institutional isomorphism and collective rationality in organisational fields. American Journal of Sociology, 48(April), 147-160. https://doi.org/10.2307/2095101

Gates, G. S. (1997). Isomorphism, homogeneity, and rationalism in university retrenchment. The Review of Higher Education, 20(3), 253-275. https://doi.org/10.1353/rhe.1997.0001

Greenwood, R., \& Hinings, C. R. (1996). Understanding radical organizational change: Bringing together the old and the new institutionalism. Academy of Management Review, 21, 1022-1054. https://doi.org/10.5465/amr.1996.9704071862

Gumport, P. (2000). Academic restructuring: Organizational change and institutional imperatives. Higher Education, 39, 67-91. https://doi.org/10.1023/A:1003859026301

Hammer, S., \& Star, C. (2004). Higher education for community and citizenship? Education and Social Action Conference, 6-8 December, Sydney, Australia.

Jones, G. A. (2006). Restructure of academic work: Themes and observations. Higher Education in Europe, 31(3), 317-325. https://doi.org/10.1080/03797720601058880

Major, M., \& Hopper, T. (2003). Extending new institutional theory: A case study of activity-based costing in the Portuguese telecommunications industry. 7th Interdisciplinary Perspectives on Accounting (IPA) Congress, Madrid, (pp. 1-59).

Maspesela, M., \& Hay, H. R. (2006). The effect of change and transformation on academic staff and job satisfaction: A case of a South African university. Higher Education, 52, 711-747. https://doi.org/10.1007/s10734-004-6821-7

Meek, V. L. (2002). On the road to mediocrity? Governance and management of Australian higher education in the market place. In A. Alberton, G. A. Jones, \& B. Karseth (eds.) 


\section{Macrothink}

International Journal of Learning and Development ISSN 2164-4063

Governing higher education: National perspective on institutional governance. Netherlands: Kluwer Academic Publishers. https://doi.org/10.1007/978-94-015-9946-7_12

Moll, J., \& Hoque, Z. (2004). Rational-legal budgeting, notions of legitimacy and power within a university environment: A case study. Presented at the Fourth Asia Pacific Interdisciplinary Research in Accounting Conference, 4 July, Singapore.

Morphew, C., \& Huisman, J. (2002). Using institutional theory to reframe research on academic drift. Higher Education in Europe, 27(4), 491-506. https://doi.org/10.1080/0379772022000071977

Parker, L. D. (2011). University corporatisation: Driving redefinition. Critical Perspectives on Accounting, 22, 434-450. https://doi.org/10.1016/j.cpa.2010.11.002

Parker, L. D. (2012). Qualitative management accounting research: Assessing deliverables and relevance. Critical Perspectives on Accounting, 23(1), 54-70. https://doi.org/10.1016/j.cpa.2011.06.002

Parker, L. D. (2013). Contemporary university strategizing: The financial imperative. Financial Accountability \& Management, 29(1). https://doi.org/10.1111/faam.12000

Santiago, R., Carvalho, T., Amaral, A., \& Meek, V. (2006). Changing patterns in the middle management of higher education institutions: The case of Portugal. Higher education, 52, 215-250. https://doi.org/10.1007/s10734-004-2747-3

Scott, W. R. (2004). Institutional theory: Contributing to a theoretical research program. Chapter in K. G. Smith \& M. A. Hitt (eds.) Great Minds in Management: The Process of Theory Development, Oxford, UK: Oxford University Press.

Scott, W. R. (2008). Approaching adulthood: The maturing of institutional theory. Theory and Society, 37, 427-442. https://doi.org/10.1007/s11186-008-9067-z

Shaw, M. M. (2013). Impacts of Globalization on the Academic Profession: Emerging Corruption Risks in Higher Education. In G. Sweeney, K. Despota, \& S. Lindner (eds.) Global Corruption Report: Education, Transparency International, 194-202. Abingdon: Earthscan by Routledge.

Shin, J. C., \& Jung, J. (2014). Academics job satisfaction and job stress across countries in the changing academic environments. Higher Education, 67, 603-620. https://doi.org/10.1007/s10734-013-9668-y

Porter, P., \& Vidovich, L. (2000). Globalization and higher education policy. Educational Theory, 50(4), 449-465. https://doi.org/10.1111/j.1741-5446.2000.00449.x

Taylor, J., \& Bedford, T. (2004). Staff perceptions of factors related to noncompletion in higher education. Studies in Higher Education, 29(3). https://doi.org/10.1080/03075070410001682637

Taylor, T., Gough, J., Bundrock, V., \& Winter, R. (1998). A bleak outlook: Academic staff perceptions of changes in core activities in Australian higher education 1991-96. Studies in 


\section{Macrothink}

International Journal of Learning and Development

ISSN 2164-4063 2021, Vol. 11, No. 3

Higher Education, 23(3), 269-279. https://doi.org/10.1080/03075079812331380246

Vaira, M. (2004). Globalization and higher education organizational change: A framework for analysis. Higher Education,

https://doi.org/10.1023/B:HIGH.0000046711.31908.e5

Winter, R., \& Sarros, J. (2002). The academic work environment in Australian universities: A motivating place to work? Higher Education Research \& Development, 21(3), 241-258. https://doi.org/10.1080/0729436022000020751

\section{Copyright Disclaimer}

Copyright for this article is retained by the author(s), with first publication rights granted to the journal.

This is an open-access article distributed under the terms and conditions of the Creative Commons Attribution license (http://creativecommons.org/licenses/by/4.0/). 